\title{
Fra den norske radesyken til de prostit glimt fra en sykdoms historie
}

I det følgende skal hudsykdommene brukes for å sammenligne to vitensregimer innenfor den medisinske virkelighet i Norge på 1800tallet. Så kan man spørre: Hvorfor hud? Hudsykdommene får sjelden de store avisoverskrifter i dag, men for to hundre år siden befant de seg i kjernen av den medisinske virkelighet. I 1822 fantes det i hele landet så mye som 1000 pasienter innlagt med hudsykdommer, fordelt på i alt 16 sykehus for «venerisk syke, Radesyge og andre ondartede Hudsygdomme».

\section{RADESYGEN}

La oss begynne med Radesygen. Ordet er knapt kjent i dag, men i sørvestnorske dialekter har ordet rata eller rada hatt betydningen dårlig, elendig eller vond. Sykdommen bestod i svære sår på armer, ben, og i ansikt, og ofte ga den store misdannelser fordi skjelettet også ble angrepet. Sørvestlandet var hardest rammet, og sykdommen førte til stor bekymring hos de sentrale myndigheter i København. På slutten av 1700-tallet og utover på 1800-tallet ble det produsert en anselig mengde litteratur om radesyken. En av de som uttalte seg var en av 1700-tallets medisinske autoriteter, Christian Elovius Mangor. I boka Underretning om Radesygens kiendetegn, Aarsager og Helbredelse, utgitt i 1793, skriver han: «Nu kommer det Tilfælde, som nok har givet
Sygen Navn af Saltflod, Stygsygen, Radesygen, og saa videre, nemlig de fæle Saar. Deres Begyndelse er enten Knuderne, der gaae i Bolning; eller Pletterne, der betændes, aabne sig og blive til ædende Saar; eller store Fnatteblegne, der revne og udbrede sig eller de komme af Stød, Frost, Rosen, eller saadanne enkelte Leiligheder. De have ingen eensdannet Skikkelse hos alle, eller paa heele Legemet, men har forskiellige Figurer. De ere ei meget dybe; hos de fleste bleegrøde, hos nogle mørkebrune og ujevne, med en haard rødblaa Rand, og give ingen god Materie, men en skarp vandagtig Vædske, som ofte er rødagtig, og noget hen i Sygdommen næsten altiid stinkende, som meget giennemsvedte strømper og Linned, eller svedige ildestinkende Fødder. Skorpen eller Roen paa dem, er som oftest sortebrun paa de Saar, som komme af Knopperne og Pletterne, men oftest hvidagtig paa dem af Ringorme og Fnat; for resten rødagtig og som paa andre Saaar ...(s 18). Aarelader man i den Tiid, da Saarene bolne stærkt og voxe, da finder man blodet bedækket med en graa eller blaaagtig skorpe, som bliver tykkere og seyere, jo meer Sygen tages til; men det underste Blod er meget sort og løst.»

\section{FREMMED TEKST}

Mangor var stadsphysicus i København og i tillegg medlem av Collegium Medicum, tidens øverste autoritet i medisinalsaker. Fra 1864 til 1865 hadde han vært ansatt ved det første sykehuset som ble opprettet bare for de radesyke, i Kristiansand. Men selv om han ikke var der så lenge, hadde Mangor åpenbart fattet nok interesse for sykdommen til å skrive en hel bok om den nesten 30 år senere. Det er en for oss fremmed tekst, et ordmylder vi ikke er vant til og en klassifikasjon som forbauser. Bare 59 år etter, i 1852, publiserer Carl Wilhelm Boeck Klinik over Hudsygdommene og de syphilitiske Sygdomme i Norsk Magazin for Lægevidenskaben. Året før var han blitt utnevnt til professor i Medisin ved universitetet, og han arbeidet ved Rikshospitalets hudavdeling. Forskjellene mellom denne teksten og den forrige er åpenbare: «De syphilitiske Hudexcrescentser vise en stor Mangfoldighed i Formen, paa den ene Side tabe de sig umærkeligt i de flade, maculöse Eruptioner, paa den anden side kunne de opnaae en meget betydelig Störrelse, og forvexles med andre Svulster. De inddeles af forskjellige Forfattere paa forskjellig Maade, men den simpleste Inddeling er den i brede og spidse. ... Bärensprung har nøiere undersögt disse forskjellige Formationer, og fundet saavel i de spidse som brede Condylomer de samme histologiske Forhold. De ere begrundede i en 


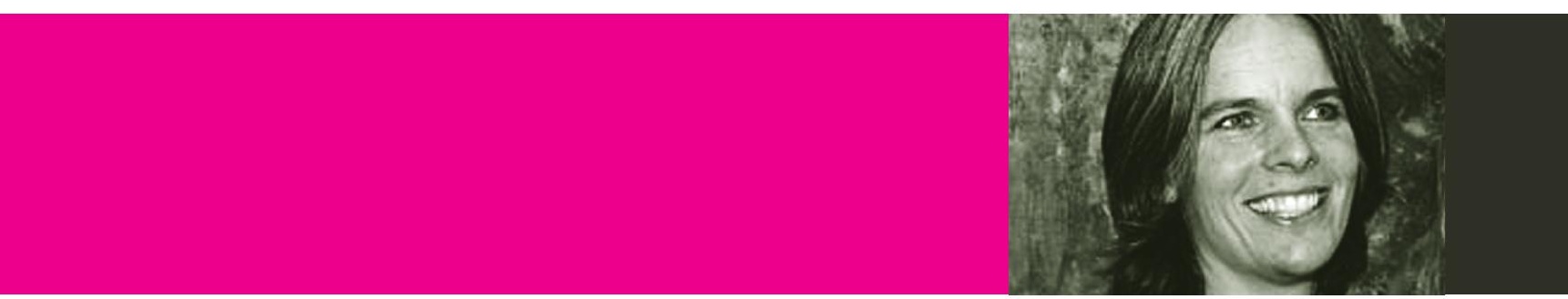

\section{uertes syfilis:}

Degeneration af enkelte Dele af Huden, nemlig Epidermis, Papillarlegemet og Haarbalgen. Paa et begrændset Sted af Huden hypertrophiere først Papillerne jevnt, og det overliggende Epidermislag fortykkes, saaledes at Condylomet i Begyndelsen viser sig som en flad, glat Ophøining. Haarfolliklernes Glandulæ sebaceæ holde sig nogen Tid, men forsvinde dog ogsaa tildidst, naar Condylomerne komme til en höiere Udvikling; og ganske det samme finder Sted ved Svedglandlerne.»

\section{KROPP OG SYKDOM}

$\mathrm{Ta}$ en titt på den første teksten igjen og sammenlign; det er store forskjeller. Men hvordan skal disse forskjellene beskrives? Inntil for noen tiår siden var det vanlig å betrakte tiden før 1850 som en vitenskapens forgård, en tid «full av spekulative vidløftigheter» som en lege skriver i 1963. De spekulative vidløftighetene skulle skyldes at legene stolte mer på to tusen år gammel teori enn på hva deres sanser kunne ha fortalt dem. Vi kunne altså avfeie alt som står i den eldre teksten som tomt tåkeprat, og hevde at i Boecks tekst er språket endelig blitt vitenskapelig og teksten empirisk forankret. Omsider har legene skjønt at de må oppsøke huden i mikroskopet, pasienten ved sykesenga og den døde kroppen på obduksjonsbordet for å få rede på hvordan virkeligheten ser ut.
Imidlertid går det også an å hevde at tekstene representerer to forskjellige måter å tenke omkring kropp og sykdom på som ikke er direkte sammenlignbare. Den kroppen Mangor møter på 1700tallet er en helt annen enn den Boeck forholder seg til på 1850tallet. Huden eksisterer ikke annet enn som overflate for ham, og det er ikke manglende kunnskap som gjør at han ikke skjærer ut et hudsnitt og ser på det i mikroskopet. Før den patologiske anatomis æra - i Frankrike kom gjennombruddet mellom 1780 og 1820, mens Norge fikk sitt første professorat i patologisk anatomi først i 1866 - var det ikke så interessant for legen å gå til den døde kroppen for å få svar på sykdomsgåten. På Mangors tid trodde man at sykdommen kom utenfra, og dermed ble den enkeltes individuelle kropp betraktet som et negativt og forurensende element. På samme måte som Linné plasserte botaniske planter i arter og familier, forsøkte legene ved hjelp av symptomene å plassere den enkelte sykdom i forhold til andre sykdommer i et skjema av arter og klasser. Sykdommen tok bare tilfeldigvis bolig i den enkelte kropp, derfor ble det ikke så viktig å finne ut hva den forårsaker av kroppslige forandringer. Det viktige var hva som skjedde på overflaten, det som er synlig. Mangor er således svært opptatt av de synlige små forskjellene; her er nitidige fargedistink- sjoner som «rødagtig», «blegrød», «mørkebrun», «sortebrun», «rødbrun», «rødblaa», «hvidagtig», «graa», «blaaagtig» og «meget sort». Videre er det i denne medisinske verden viktigere å nevne de «svedige føtter» og den «vandagtige Vædske» enn eventuelle organiske forandringer, som like gjerne kunne være tilfeldige.

\section{UNDER OVERFLATEN}

I den anatomisk-kliniske medisin blir legens blikk, derimot, et blikk som borer i dybden. Endringen er åpenbar i Boecks tekst som er sitert over. Selve språket er mye nærmere vårt eget vitenskapelige språk - 150 år etter at teksten ble skrevet - enn språket i Mangors tekst, som bare lå 60 år bak i tid. Professor Boeck taler så og si fra mikroskopet, med blikket heftet fast i det histologiske snittet. I løpet av disse 60 årene har det oppstått en helt ny hud; en hud som er lagdelt og mangfoldig, som klassifiseres i henhold til makulæe (flekker), papulæe (blemmer) og condylomer (vorter), som har strukturer som epidermis (ytterhuden) og Papillarlegemet (innenfor denne), og som inneholder elementer som glandula sebacea (fettkjertler) og svettekjertler. Det dreier seg om en hud som i store trekk er slik vi kjenner den i dag. Og mer interessant: det er forandringer i denne huden som utgjør sykdommen syfilis; her beskrevet som 
fortykkelse av hudens forskjellige lag i en bestemt rekkefølge. Det må undersøkes hvor i huden den sykelige forandringen er, hvilke deler av den som skades, og hvilke funksjonelle endringer dette fører til. Plutselig er det altså blitt viktig å finne ut hva som befinner seg nedenfor overflaten, bak sårene, og før sårene. Det er ikke lenger slik at sykdommen slår seg ned i en tilfeldig kropp, den har ingen eksistens uavhengig av kroppen, og kan først bestemmes endelig ved åpningen av den syke kroppen etter døden. Legens øye fokuserer nå på en syk organisme, ikke på en ideell sykdomsart, som idéhistorikeren Michel Foucault har påpekt. Ser man utviklingen på den måten blir det åpenbart at Mangor var i besittelse av en kunnskap som er gått tapt. Det var ikke slik at han visste mindre enn Boeck, han visste noe annet. Og dette andre vet vi i dag svært lite om, derfor virker teksten så fremmed for oss.

\section{SYFILIS}

Det medisinske blikket var annerledes i 1860 enn i 1793, men det var den fysiske virkelighet dette blikket så også. Boeck hadde faktisk en egen «Service» til rådighet ved Rikshospitalets hudavdeling der pasientene inngikk i en medisinsk-eksperimentell behandlingssituasjon. Hans «Service» kan sees som et laboratorium der kliniske forsøk kunne drives under kontrollerbare forhold med mange pasienter. Her utfører han behandlingsforsøk med syfilisasjon, det vil si inokulasjon av syfilitisk materiale på syfilispasienter, i den hensikt å oppnå styrking av immunforsvaret. En slik sammenblanding av forskning/ekspe- riment og pasientbehandling var helt utenkelig på slutten av 1700tallet. For Boeck er den kliniske og teoretiske praksis svært intimt forbundet, for Mangor er det ikke slik. For ham er teori og praksis atskilte felter. Han hadde fått undervisning i teoretisk medisin på universitetet og praktisk opplæring på det kongelige Fredriks hospital. Han behandlet pasientene i deres naturlige element; hjemme hos familien, og sendte de som ikke hadde omsorg hjemme til hospitalene. Der ble det drevet omsorg, men ingen utstrakt behandling, og ingen forskning $i$ vår forstand. Rundt midten av 1800-tallet er Rikshospitalet i ferd med å bli en forskningsinstitusjon, der kunnskap produseres ved at stadig større pasientmasser blir gjenstand for systematisk observasjon og objekter for undervisning. Slik blir produksjonsbetingelsene for kunnskap også helt annerledes enn på 1700-tallet.

\section{IDEOLOGISKE FøRINGER}

Også faktorer som det ikke står om i de klassiske vitenskapshistoriske fremstillinger er uløselig forbundet med kunnskapsutviklingen. I vårt tilfelle dreier det seg blant annet om rekrutteringen av pasienter til Boecks kliniske forsøk. For det første var det et generelt trekk ved samtidens sykehus at pasientene hovedsakelig var rekruttert fra de lavere klasser, de mer velstående ble fremdeles behandlet i sine hjem. Dette gjaldt sannsynligvis i særlig grad for Boecks klinikk, da sykdommen syfilis hadde sterke moralske konnotasjoner og førte til at pasientene ofte foretrakk privat behandling dersom de hadde økonomisk mulighet. En spesiell pasientgruppe utgjorde de prostituerte, som var rekruttert ved hjelp av den ukentlige legevisitasjonen som ved lov var pålagt alle prostituerte fra 1842 til 1888 (men ingen menn, selv om disse utgjorde en større del av de syke). For det andre var forsøkene på Boecks Service ved hudavdelingen etter all sannsynlighet ikke frivillige. En engelsk lege ved navn Hutchinson skrev bestyrtet hjem om tvangsbehandlingen ved enheten og om piggtrådgjerder rundt hudavdelingen. Det lå altså klare ideologiske føringer til grunn for den nye kunnskapstilegnelsen.

I samme tekst som vi har referert over, men litt senere enn det siterte avsnittet, kommenterer Boeck Mangors beskrivelser om radesyken, og karakteriserer dem som upresise og uvitenskapelige. Mangor skjønte ikke, hevdet han, at Radesyken egentlig var en form for syfilis $i$ et avansert stadium. Følgelig: «Navnene Radesyge og Theria ville, eftersom Studiet af Hudsygdommene og de syphilitiske Sygdomme hos os gaaer fremad, efterhaanden forsvinde». Kanskje han skulle ha vært litt mer ydmyk. Det han selv kjempet så iherdig for, syfilisasjonen, ble allerede noen tiår etter publikasjonen av denne teksten støtt ut i pseudovitenskapens grenseland. Så mens navnet Radesyge holdt seg i over hundre år, så fikk syfilisasjonen en mye kortere levetid, bare rundt 20 år. Historien tar av og til en grusom hevn.

\section{Dette essayet er en bearbeidet}

versjon av en artikkel som har stått på trykk i Museumsnytt: «Fra fnatteblegne til syfilisasjon - mot en moderne medisin i Norge». 